\title{
HYDROGEN PEROXIDE PROMOTES HUMAN SKIN FIBROBLAST CELLS MIGRATION AND PROLIFERATION AT LOWER DOSE VIA VEGF- $\alpha$ AND TGF- $\alpha$ GENE EXPRESSION
}

\author{
NUR SYAKIRAH MAHAMAD AZIZ1 ${ }^{1}$, JOHNSON STANSLAS ${ }^{2}$ \\ and NURUL HUDA ABD KADIR ${ }^{1,3^{*}}$ \\ ${ }^{1}$ Biological Security and Sustainability (BioSeS) Research Group, \\ Faculty of Science and Marine Environment, Universiti Malaysia Terengganu, \\ 21030 Kuala Nerus, Terengganu, Malaysia \\ ${ }^{2}$ Faculty of Medicine and Health Sciences, University Putra Malaysia, \\ 43400 Serdang, Selangor \\ ${ }^{3}$ Institute Aquaculture Tropical, Universiti Malaysia Terengganu, \\ 21030 Kuala Terengganu, Terengganu, Malaysia \\ EE-mail: nurulhuda@umt.edu.my
}

Accepted 10 December 2020, Published online 25 December 2020

\begin{abstract}
Hydrogen peroxide $\left(\mathrm{H}_{2} \mathrm{O}_{2}\right)$ and oxygen $\left(\mathrm{O}_{2}\right)$, reactive oxygen species (ROS) that are formed during wound healing. Excessive exposure to $\mathrm{H}_{2} \mathrm{O}_{2}$ may lead to oxidative stress in cells. However, the low or moderate dosage of $\mathrm{H}_{2} \mathrm{O}_{2}$ might help in the wound healing process. AlamarBlue ${ }^{\mathrm{TM}}$ cell viability, scratch assay, and qRT-PCR analysis were done to evaluate cell viability, cell migration and gene expression of VEGF- $\alpha$ and TGF- $\alpha$ on the skin fibroblast cells treated with $\mathrm{H}_{2} \mathrm{O}_{2}(0$ to $50 \mu \mathrm{M})$, respectively. Our results have shown that the fibroblast cells were significantly proliferated and migrated after treated with $\mathrm{H}_{2} \mathrm{O}_{2}(12.5 \mu \mathrm{M}, 25 \mu \mathrm{M}$, and $50 \mu \mathrm{M})$ at $48 \mathrm{~h}$ and $72 \mathrm{~h}$ of exposure when compared to control. Furthermore, VEGF- $\alpha$ gene expression on treated fibroblast cells $(50 \mu \mathrm{M})$ was found to be higher than control, whereas TGF- $\alpha$ gene expression was slightly lower than control. This result suggesting that cell proliferation and migration was possibly due to the activation of VEGF- $\alpha$ but not TGF- $\alpha$ gene.
\end{abstract}

Key words: Hydrogen peroxide, proliferation, migration, skin fibroblast cells

\section{INTRODUCTION}

Our body has its way of healing and protecting a wound from being invaded by pathogen where a tissue damaged will trigger a cascade of repair events which begin with the formation of a fibrin clot (Soneja et al., 2015). When there is a leakage of blood, the blood clot will form to protect the underlying tissues and serves as a provisional matrix through which cells can move and also acts as a reservoir for growth factors and cytokines (Clark, 2001). According to U Auf dem Keller et al. (2006), various inflammatory cells like neutrophils, macrophages (phagocytes), endothelial cells and fibroblasts produce superoxide during the process of wound healing, where the superoxide can quickly

* To whom correspondence should be addressed. dismutase to hydrogen peroxide $\left(\mathrm{H}_{2} \mathrm{O}_{2}\right)$ (broadly known as a cytotoxic agent) and oxygen $\left(\mathrm{O}_{2}\right)$ by constitutive and inducible superoxide dismutases (SOD). Superoxide is strong oxidants and is the main component of reactive oxygen species (ROS) which can contribute to oxidative damage in cells (López-Lázaro, 2007). $\mathrm{H}_{2} \mathrm{O}_{2}$ is one of the ROS byproducts of cellular respiration, protein folding, and end products of several metabolic reactions other than superoxide anion $\left(\mathrm{O}^{-}\right)$and hydroxyl radical (OH) (Reczek \& Chandel, 2015).

Sen (2003), stated that oxidants play an important role in wound healing by providing signalling and defence against microorganisms and is involved in the induction of tissue factor (TF)-mRNA and reepithelization the wounds (Soneja et al., 2015). ROS such as $\mathrm{OH}, \mathrm{O}_{2^{-}}, \mathrm{H}_{2} \mathrm{O}_{2}$ and nitric oxide (NO) are produced during normal metabolism 
in cells and several studies have proved that $\mathrm{H}_{2} \mathrm{O}_{2}$ promote wound healing by inducing vascular endothelial growth factor (VEGF) expression, TGF- $\beta 1$, anchorage-independent growth and fibroblast proliferation (Park et al., 2001) However, despite the importance of ROS, excessive production of ROS in an organism may also lead to oxidative stress where a disturbance in an imbalance of oxidant and antioxidant production causes damage to the cell (Halliwell \& John, 1999; Alisi \& Onyeze, 2008). Low or moderate level of ROS serves as signalling and regulatory molecules that may enhance wound healing and also to inhibit bacteria growth (Amir Aslani \& Ghobadi, 2016).

Migration phase comes almost at the same time as proliferation phase as which during those phases, endothelial cells, epithelial cells and fibroblast cells migrate into the wound area. The inflammatory cells migrate into the wound (chemotaxis) once the bleeding is controlled and promote the inflammatory phase which is characterized by the sequential infiltration of neutrophils, macrophages and lymphocytes (Gosain \& DiPietro, 2004; George Broughton et al., 2006; Guo \& DiPietro, 2010). Even though neutrophils produce substances such as proteases and reactive oxygen species (ROS) that cause some oxidative stress, but the ROS is vital in inhibiting pathogenic microorganisms, cellular debris in the wound area (Guo \& DiPietro, 2010). ROS also demonstrated to enhance keratinocytes and fibroblast growth (Soneja et al., 2015). Although $\mathrm{H}_{2} \mathrm{O}_{2}$ has been underestimated for its function in wound healing, many researchers have finally acknowledged the existence of $\mathrm{H}_{2} \mathrm{O}_{2}$ and its importance in intracellular signalling pathways and regulating a variety of biological functions, such as cell proliferation and migration (Droge, 2002; Benhar et al., 2002; Veal et al., 2007; Shibata et al., 2013).

Interestingly, previous studies have shown that $\mathrm{H}_{2} \mathrm{O}_{2}(3 \%)$ has been used by clinicians to disinfect wounds. Furthermore, a low level of $\mathrm{H}_{2} \mathrm{O}_{2}$ was reported to enhance dermal wound healing ( $\mathrm{Zhu}$ et al., 2017). On the other hand, $\mathrm{H}_{2} \mathrm{O}_{2}$ at a concentration above $3 \% \mathrm{H}_{2} \mathrm{O}_{2}(980 \mathrm{mM})$ was reported by Roy et al. (2006), to delay the healing process of mice dorsal skin. The contradiction findings may lead to an adverse effect in treating wounds. We speculated that the concentrations of the $\mathrm{H}_{2} \mathrm{O}_{2}$ play a role in promoting wounds healing. Therefore, this experiment aims to evaluate $\mathrm{H}_{2} \mathrm{O}_{2}$ at various doses $(0-50 \mu \mathrm{M})$ in promoting fibroblast cells proliferation, a migration that may enhance wound healing.

\section{MATERIALS AND METHODS}

\section{Cell proliferation assay}

The AlamarBlue ${ }^{\mathrm{TM}}$ (Invitrogen, USA) assay is based on the ability of viable cells to metabolically reduce the dye resazurin. Viable cells metabolise the dye by mitochondrial-dependent reduction to give a product that can be measured in a multimicroplate reader whereas, for dead cells, the dye could not be converted to a fluorescence product. Human skin fibroblast cells, CRL-2522, from the American Type Culture Collection (ATCC) were harvested and seeded $(10,000$ cell/well $)$ in 96 well plates containing Eagle's Minimum Essential Medium (EMEM) (ATCC, USA) and incubated overnight to equilibrate. $10 \mu \mathrm{L}$ of $\mathrm{H}_{2} \mathrm{O}_{2}$ (R\&M, Malaysia) were added into $90 \mu \mathrm{L}$ media containing cells to give final concentrations of $0 \mu \mathrm{M}$ (negative control), 6.25 $\mu \mathrm{M}, 12.5 \mu \mathrm{M}, 25 \mu \mathrm{M}$, and $50 \mu \mathrm{M}$. The treated fibroblast cells were incubated for $24 \mathrm{~h}, 48 \mathrm{~h}$ and $72 \mathrm{~h}$. Living cells without any treatment was used as the positive control. At each time point, AlamarBlue $^{\mathrm{TM}}(10 \mu \mathrm{L}, 0.4 \%)$ was added to each well and incubated for $4 \mathrm{~h}$. The fluorescence reading was monitored at $560 \mathrm{~nm}$ excitation wavelength and 590 $\mathrm{nm}$ emission wavelength. The cell viability was determined by the difference between treated and control cells, as indicates below:

Percentage cell viability $(\%)=\frac{\text { Fluorescence of samples }}{\text { Fluorescence of control }} \times 100$

\section{Cell migration assay}

A migration assay was performed to determine the effects of $\mathrm{H}_{2} \mathrm{O}_{2}$ on fibroblast cells motility in 24 wells plate. Fibroblast cells were seeded at $10.0 \times 10^{5}$ cells per well in EMEM and grown until $80-90 \%$ confluence was reached. Subsequently, all of the well-containing cells were scratched in the middle using sterile $200 \mu \mathrm{L}$ tip and were rinsed with sterile phosphate buffer saline (PBS) (Sigma, UK) to prevent unattached cells to adhere onto the migration area. The cells were treated with serial dilutions of $\mathrm{H}_{2} \mathrm{O}_{2}$ in EMEM without fetal bovine serum (FBS) (ATCC, USA). The negative control used for $\mathrm{H}_{2} \mathrm{O}_{2}$ was deionized water and positive control was medium (EMEM) with FBS. The cells were treated for $0 \mathrm{~h}, 24 \mathrm{~h}, 48 \mathrm{~h}$ and $72 \mathrm{~h}$ and were viewed to observe the migration of the cell towards the gap area. The gap area or wound closure was calculated as below:

$$
\% \text { wound closure }=\frac{\mathrm{A} 0(\mathrm{~mm})-\operatorname{At}(\mathrm{mm})}{\mathrm{A} 0}
$$


A0 indicates the original wound area (day 0) and At is the area of the wound at a specific time after wounding.

\section{qRT-PCR analysis for TGF- $\alpha$ and VEGF- $\alpha$ gene expression}

Fibroblast cells were seeded (100,000 cell/flask) in 15 containers of T75 flask and were incubated overnight to equilibrate. $1 \mathrm{~mL}$ of each sample with the desired concentration was put into the flask in triplicate and were incubated for $24 \mathrm{~h}$. After $24 \mathrm{~h}$, the cells were harvested and the cell pellets were contained by centrifugation. Then, $0.5 \mathrm{ml}$ of TRIZOL was added to the pellet to lyse the cells and the pipetting was repeated for the homogenisation process. The homogenized samples were incubated for 5 minutes at room temperature to allow complete dissociation of nucleoprotein complexes. After 5 min, the samples were transferred to $1.5 \mu \mathrm{L}$ microfuge tubes. Total RNA was extracted from each specimen using the LS Trizol reagent (Invitrogen Ltd, UK) according to the manufacturer's protocol. RNA concentration and purity were determined on a UV/VIS spectrophotometer (Hitachi Instruments Inc., USA) by evaluation of the A260/A280 ratios. RNA integrity was examined by denaturing polyacrylamide gel electrophoresis.

For mRNA reverse transcription, RNA extracts (100-500 ng) from each sample were added to 300 ng of random primers, heated for $5 \mathrm{~min}$ at $65^{\circ} \mathrm{C}$ and then immediately placed on ice. Each sample was incubated with $0.5 \mathrm{mM}$ dNTPs, $1 \times$ first strand buffer, $8 \mu \mathrm{M}$ dithiothreitol and 100 units of Superscript II reverse transcriptase (Invitrogen, Life technologies) for $10 \mathrm{~min}$ at $25^{\circ} \mathrm{C}, 90 \mathrm{~min}$ at $42^{\circ} \mathrm{C}$ and $15 \mathrm{~min}$ at $70^{\circ} \mathrm{C}$ on a thermocycler (Peltier Thermal Cycler PTC-200, MJ Research, Waltham, Massachusetts, USA). An mRNA reverse transcription kit was used for mRNA expression according to the manufacturer's protocol (Taqman, Applied Biosystems, Life technologies). QuantitativePolymerase Chain Reaction (qPCR) was performed using pre-designed gene expression assays and FAST PCR master mix (Taqman, Applied Biosystems, Life technologies), and measured in a StepOnePlus fast real-time PCR system (Applied Biosystems, Life Technologies) according to the manufacturer's protocol. GAPDH expression was used to normalize cellular mRNA expression. Gene expression was quantified using the delta-Ct method.

\section{RESULTS AND DISCUSSION}

\section{Cell proliferation assay}

ROS are produced in the body during normal metabolism and are known for playing a dual role as both deleterious and beneficial species (Marinho et al., 2014). ROS such as $\mathrm{H}_{2} \mathrm{O}_{2}$ in the cellular process is involved in growth factor signalling, autophagy, immune responses, and stem cell proliferation and differentiation events (Reczek \& Chandel, 2015). Our result for fibroblast cells proliferation in Figure 1, has shown a gradual increase of cell viability after treated with all the concentration of $\mathrm{H}_{2} \mathrm{O}_{2}(12.5 \mu \mathrm{M}, 25 \mu \mathrm{M}$, and 50 $\mu \mathrm{M})$ at $24 \mathrm{~h}, 48 \mathrm{~h}$ and $72 \mathrm{~h}$. A similar finding was reported by Kim et al. (2001), which demonstrated that $\mathrm{H}_{2} \mathrm{O}_{2}(1 \mu \mathrm{M}-250 \mu \mathrm{M})$ promoted proliferation of Chinese Hamster Lung Fibroblast (V79) cells and the proliferation effect was due to activation of mitogen-activated protein kinases (MAPK) proteins such as p38 MAPK and Jun-N-terminal kinase (JNK). Besides, Ito et al. (2011), reported that low concentration $(20 \mu \mathrm{M}$ to $500 \mu \mathrm{M})$ of $\mathrm{H}_{2} \mathrm{O}_{2}$ enhanced rat astrocytes growth by activating FGF-1 and cytosolic proteins such as HSP 70, HSP, 90, PK-C $\delta$, and $\beta$-actin without inducing cell death.

\section{In vitro scratch assay}

To prove whether the cells proliferation effect may enhance the cells migration of the cells, we conducted an in vitro scratch assay as a mimic to wound healing closure. According to Liang et al. (2007), the in vitro scratch assay is an inexpensive protocol that is suitable to study effects of cellmatrix and cell-cell interactions during the migration of the cells which mimicking cell migration during wound healing for animal study. Figure 2 shows that

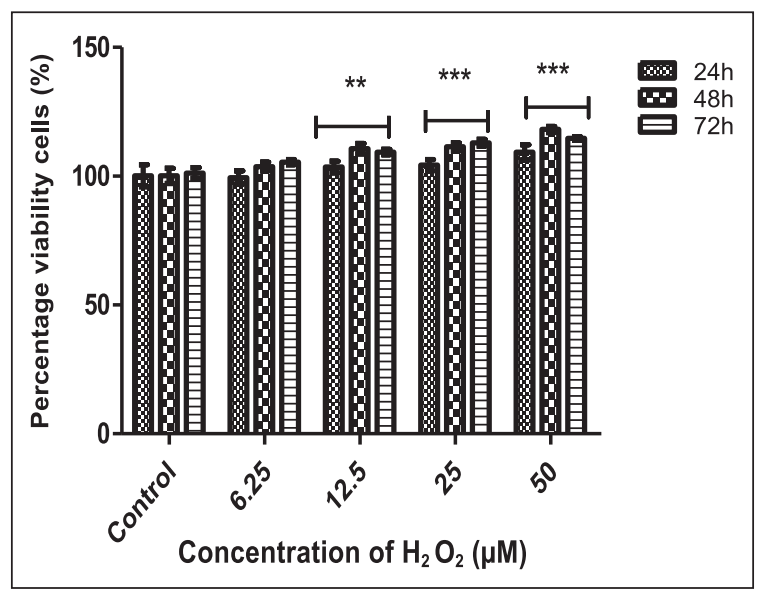

Fig. 1. Percentage of cell viability (\%) of fibroblast cell after treated with different concentration of $\mathrm{H}_{2} \mathrm{O}_{2}(0 \mu \mathrm{M}$ (negative control), $6.25 \mu \mathrm{M}, 12.5 \mu \mathrm{M}, 25 \mu \mathrm{M}$, and $50 \mu \mathrm{M}$ ) for 24,48 and $72 \mathrm{~h}$ treatment on the viability of human fibroblast cell lines. This AlamarBlue ${ }^{\circledR}$ Cell Viability Assay was performed fluorometically at $570 \mathrm{~nm}$ for excitation and $590 \mathrm{~nm}$ for emission. One way ANOVA analysis (Dunnet post-test) was done interaction of dose exposure for each time point, and * indicates $\mathrm{P}<0.05$, ** indicates $\mathrm{P}<0.01$ and $* * *$ indicates $\mathrm{P}<0.001$ significant difference. Each value is the mean $\pm \operatorname{SEM}(\mathrm{n}=4)$. 


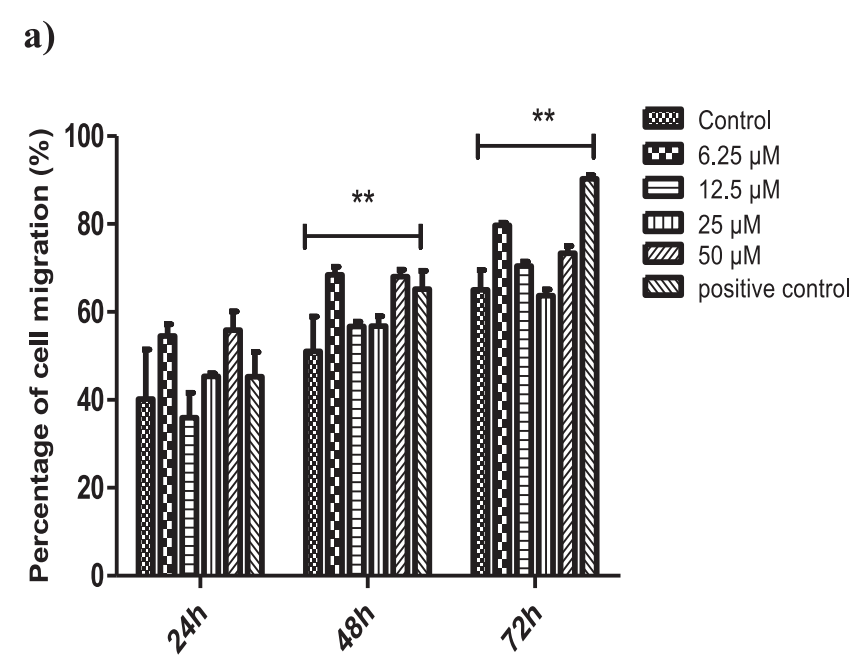

b)

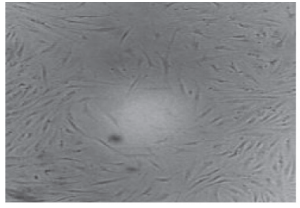

$0 \mathrm{~h}$

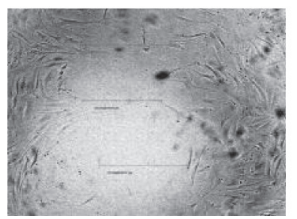

$48 \mathrm{~h}$

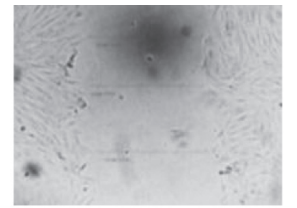

$24 \mathrm{~h}$

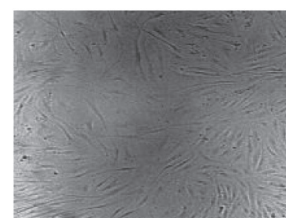

$72 \mathrm{~h}$

Fig. 2. a) migration effect of treated fibroblast cells with $\mathrm{H}_{2} \mathrm{O}_{2}$ and b) pictoral of monolayer of fibroblast cells subjected to scratch and treated with $\mathrm{H}_{2} \mathrm{O}_{2}$ at different concentration $(0 \mu \mathrm{M}$ (negative control), $6.25 \mu \mathrm{M}, 12.5 \mu \mathrm{M}, 25 \mu \mathrm{M}$, and $50 \mu \mathrm{M})$, positive control (FBS) and negative control $\left(\mathrm{dH}_{2} \mathrm{O}\right)$ at 0 hour, 24 hours, and 48 hours after incubation. Two way ANOVA analysis (Bonferroni post-test) was done to determine interaction of time and dose exposure, and $*$ indicates $\mathrm{P}<0.05$, $* *$ indicates $\mathrm{P}<0.01$ and $* * *$ indicates $\mathrm{P}<0.001$ significant difference. Each value is the mean $\pm \mathrm{SEM}(\mathrm{n}=3)$.

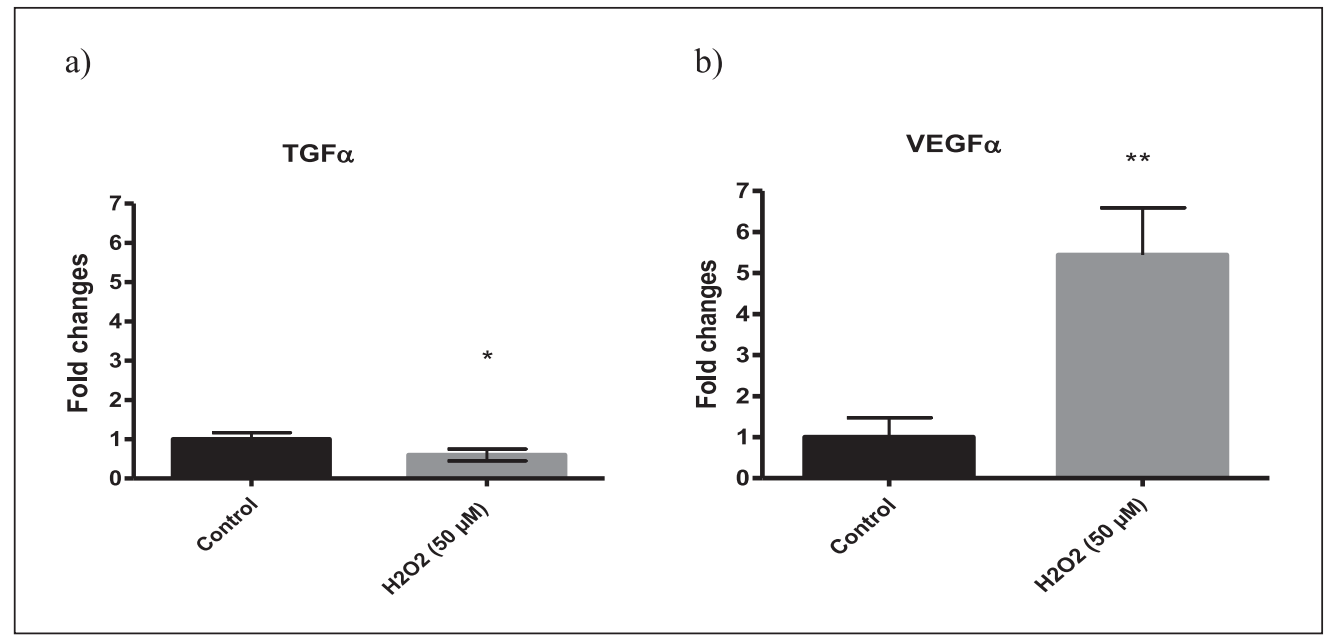

Fig. 3. a) TGF- $\alpha$ and b) VEGF- $\alpha$ genes expression of fibroblast cell treated with $50 \mu \mathrm{M}$ of $\mathrm{H}_{2} \mathrm{O}_{2}$ at 24 $\mathrm{h}$ of exposure. * indicates $\mathrm{P}<0.05$, ** indicates $\mathrm{P}<0.01$ and *** indicates $\mathrm{P}<0.001$ significant difference.

the highest concentration $(50 \mu \mathrm{M})$ at $72 \mathrm{~h}$ of $\mathrm{H}_{2} \mathrm{O}_{2}$ exposure in fibroblast cells, caused optimal cells migration as the cells migrated towards the scratched place and almost closing the scratched gap. According to Loo et al. (2012), the low dose of $\mathrm{H}_{2} \mathrm{O}_{2}(250 \mu \mathrm{M})$ exhibited re-epithelialisation and wound closure of keratinocytes. We speculated that the $\mathrm{H}_{2} \mathrm{O}_{2}$ treated-cell migration effect was due to redox signalling that regulates growth factors and change the gene expression for various cellular functions by activating the mitogenic-associated signal transduction pathways in the cell (Zhang et al., 1998; Chen et al., 2004; Huo et al., 2009).

\section{qRT-PCR analysis for TGF- $\alpha$ and VEGF- $\alpha$ gene expression}

We have chosen to conduct an experiment on fibroblast cell using $\mathrm{H}_{2} \mathrm{O}_{2}(50 \mu \mathrm{M})$ to observe the ability of the treatment to promote cell proliferation and migration due to its prominent ability in inducing cell proliferation and migration, and also to investigate the expression of VEGF- $\alpha$ and TGF- $\alpha$ gene. TGF- $\alpha$ is one of epidermal growth factor's (EGF) family and was said to control pro-inflammatory signalling and enhance cell proliferation (Müller-Deubert et al., 2017). While, VEGF was said to increase migration and also the 
proliferation of cells by influencing the behaviour of another vascular cell type (Li et al., 2009). It is shown that both TGF- $\alpha$ and VEGF- $\alpha$ genes help in the wound healing process and based on the gene expression, we believed that these two growth factors were expressed during the cell proliferation and cell migration events. Interestingly, we found that TGF- $\alpha$ gene expression in $\mathrm{H}_{2} \mathrm{O}_{2}$ was significantly low, however, VEGF- $\alpha$ gene was highly expressed. Sen et al. (2002), reported that ROS may promote wound angiogenesis in the wound site by inducing VEGF expression in woundrelated cells such as keratinocytes and but the specifics signalling pathway were remained unknown. Therefore we can say that $\mathrm{H}_{2} \mathrm{O}_{2}$ was inducing cell proliferation and migration via VEGF- $\alpha$ gene.

\section{CONCLUSIONS}

Wound healing is a complicated process and involves varieties of activities in the body. Fibroblast cell was known to be involved in the wound healing process and several growth factors like TGF- $\alpha$ and VEGF- $\alpha$ were produced to enhance the cell proliferation and cell migration, respectively. Our finding has proved that of $\mathrm{H}_{2} \mathrm{O}_{2}$ $(50 \mu \mathrm{M})$ was an optimal concentration that exhibited fibroblast cells proliferation and migration, due to activation of VEGF- $\alpha$ gene expression. Further study should be carried out to assess protein expression of VEGF and TGF as well as other related protein to assess wound healing effect of hydrogen peroxide on human skin fibroblast cells

\section{ACKNOWLEDGEMENT}

We would like to thank the Ministry of Education for funding this project (RACE grant-vote 56021 and GGP-68007/2013/126).

\section{REFERENCES}

Alisi, C.S. \& Onyeze, G.O.C. 2008. Nitric oxide scavenging ability of ethyl acetate fraction of methanolic leaf extracts of Chromolaena odorata (Linn.). African Journal of Biochemistry Research, 2(7): 145-150.

Amir Aslani, B. \& Ghobadi, S. 2016. Studies on oxidants and antioxidants with a brief glance at their relevance to the immune system. Life Sciences, 146: 163-173.
Auf Dem Keller, U., Kümin, A., Braun, S. \& Werner, S. 2006. Reactive oxygen species and their detoxification in healing skin wounds. Journal of Investigative Dermatology Symposium Proceedings, 11(1): 106-111.

Benhar, M., Engelberg, D. \& Levitzki, A. 2002. ROS, stress-activated kinases and stress signaling in cancer. EMBO Reports, 3(5): 420-425.

Chen, K.C.W., Zhou, Y., Xing, K., Krysan, K. \& Lou, M.F. 2004. Platelet derived growth factor (PDGF)-induced reactive oxygen species in the lens epithelial cells: the redox signalling. Experimental Eye Research, 78(6): 1057-1067.

Clark, R.A. 2001. Fibrin and wound healing. Annals of the New York Academy of Sciences, 936(1): 355-367.

Droge, W. 2002. Free radicals in the physiological control of cell function. Physiological Reviews, 82(1): 47-95.

George Broughton, I.I., Janis, J.E. \& Attinger, C.E. 2006. Wound healing: an overview. Plastic and Reconstructive Surgery, 117(7 Suppl): 1e-S$32 \mathrm{e}-\mathrm{S}$.

Gosain, A. \& DiPietro, L.A. 2004. Aging and wound healing. World Journal of Surgery, 28: 321 326.

Guo, S.A. \& DiPietro, L.A. 2010. Factors affecting wound healing. Journal of Dental Research, 89(3): 219-229.

Halliwell, B. \& John, M.C.G. 1999. Free Radicals in Biology and Medicine. Oxford University Press, New York.

Huo, Y., Qiu, W.Y., Pan, Q., Yao, Y.F., Xing, K. \& Lou, M.F. 2009. Reactive oxygen species (ROS) are essential mediators in epidermal growth factor (EGF)-stimulated corneal epithelial cell proliferation, adhesion, migration, and wound healing. Experimental Eye Research, 89(6): 876-886.

Ito, J.I., Nagayasu, Y., Hoshikawa, M., Kato, K.H., Miura, Y., Asai, K., Hayashi, H., Yokoyama, S. \& Michikawa, M. 2013. Enhancement of FGF-1 release along with cytosolic proteins from rat astrocytes by hydrogen peroxide. Brain Research, 1522: 12-21.

Kim, B.Y., Han, M.J. \& Chung, A.S. 2001. Effects of reactive oxygen species on proliferation of Chinese hamster lung fibroblast cells. Free Radical Biology \& Medicine, 30: 686-698.

Li, D., Zhang, C., Song, F., Lubenec, I., Tian, Y. \& Song, Q.H. 2009. VEGF regulates FGF-2 and TGF- $\beta 1$ expression in injury endothelial cells and mediates smooth muscle cells proliferation and migration. Microvascular Research, 77(2): 134-142. 
Liang, C.C., Park, A.Y. \& Guan, J.L. 2007. In vitro scratch assay: a convenient and inexpensive method for analysis of cell migration in vitro. Nature Protocols, 2: 329-333.

Loo, A.E.K. \& Halliwell, B. 2012. Effects of hydrogen peroxide in a keratinocyte-fibroblast co-culture model of wound healing. Biochemical and Biophysical Research Communications, 423: 253-258.

López-Lázaro, M. 2007. Dual role of hydrogen peroxide in cancer: possible relevance to cancer chemoprevention and therapy. Cancer Letters, 252: $1-8$.

Marinho, H.S., Real, C., Cyrne, L., Soares, H. \& Antunes, F. 2014. Hydrogen peroxide sensing, signaling and regulation of transcription factors. Redox Biology, 2: 535-562.

Müller-Deubert, S., Seefried, L., Krug, M., Jakob, F. \& Ebert, R. 2017. Epidermal growth factor as a mechanosensitizer in human bone marrow stromal cells. Stem Cell Research, 24: 69-76.

Park, S.K., Kim, J.A., Seomun, Y., Choi, J., Kim, D.H., Han, I.O., Lee, E.H., Chung, S.K. \& Joo, C.K. 2001. Hydrogen peroxide is a novel inducer of connective tissue growth factor. Biochemical and Biophysical Research Communications, 284(4): 966-971.

Reczek, C.R. \& Chandel, N.S. 2015. ROS-dependent signal transduction. Current Opinion in Cell Biology, 33: 8-13.

Roy, S., Khanna, S., Nallu, K., Hunt, T.K. \& Sen, C.K. 2006. Dermal wound healing is subject to redox control. Molecular Therapy, 13(1): 211-220.
Sen, C.K. 2003. The general case for redox control of wound repair. Wound Repair and Regeneration, 11: 431-438.

Sen, C.K., Khanna, S., Gordillo, G., Bagchi, D., Bagchi, M. \& Roy, S. 2002. Oxygen, oxidants, and antioxidants in wound healing: An emerging paradigm. Annals of The New York Academy of Sciences, 957: 239-249.

Shibata, A., Tanabe, E., Inoue, S., Kitayoshi, M., Okimoto, S., Hirane, M. \& Tsujiuchi, T. 2013. Hydrogen peroxide stimulates cell motile activity through LPA receptor-3 in liver epithelial WB-F344 cells. Biochemical and Biophysical Research Communications, 433(3): 317-321.

Soneja, A., Drews, M. \& Malinski, T. 2005. Role of nitric oxide, nitroxidative and oxidative stress in wound healing. Pharmacology Reports, 57: 108-119.

Veal, E.A., Day, A.M. \& Morgan, B.A. 2007. Hydrogen peroxide sensing and signaling. Molecular Cell, 26(1): 1-14.

Zhang, J., Jin, N., Liu, Y. \& Rhoades, R.A. 1998. Hydrogen peroxide stimulates extracellular signal-regulated protein kinases in pulmonary arterial smooth muscle cells. American Journal of Respiratory Cell and Molecular Biology, 19: 324-332.

Zhu, G., Wang, Q., Lu, S. \& Niu, Y. 2017. Hydrogen peroxide: A potential wound therapeutic target? Medical Principles and Practice, 26: 301-308. 